\title{
Changes in Renal Function and Blood Volume in the Newborn Lamb Delivered by Cesarean Section
}

\author{
KAREN J. GIBSON AND EUGENIE R. LUMBERS
}

School of Physiology and Pharmacology, University of New South Wales, Kensington, New South Wales, Australia

\section{ABSTRACT}

To determine the cause of the transient natriuresis in lambs within 1-2 $\mathrm{h}$ of birth, renal function and blood volume (BV) were measured in nine chronically catheterized fetal sheep aged 139-145 d before and after delivery by cesarean section. After delivery, sodium excretion increased 8-fold. This was due to a transient rise in glomerular filtration rate (by $39 \pm 21 \%, p<0.02$ ) and a fall in fractional reabsorption of sodium by the proximal tubule from $63.4 \pm 2.5 \%$ to $53.4 \pm 3.4 \%(p<0.01)$. The distal tubule failed to compensate fully for this fall, because fractional reabsorption by the distal tubule rose from 35.5 $\pm 2.4 \%$ to only $41.6 \pm 2.2 \%(p<0.05)$. The extent of the natriuresis did not depend on the lamb's initial BV per kg at birth. However, the amount of fluid excreted and the clearance of sodium during a 45-min period within the first 1-1.25 h after birth were approximately equal to the fall in BV that occurred during this time. Thus, most of the fall in

After birth, human infants have a transient increase in urine flow rate (1). Similarly, lambs delivered by cesarean section at 139-145 $\mathrm{d}$ have a transient natriuresis and disruption of glomerulotubular balance (2). It has been suggested that volume expansion of the newborn, resulting from placental blood transfusion, may contribute to this diuresis (3). We postulated that lambs with larger BV relative to their weights would show a greater natriuresis than lambs with smaller BV per kg body weight. It should be noted that because it was not possible to measure partitioning of the fetal BV between the fetal body and the placenta before birth, it could not be determined whether placental transfusion occurred with delivery.

Received April 20, 1993; accepted May 10, 1994.

Correspondence and reprint requests: Dr. K. J. Gibson, School of Physiology and Pharmacology, University of New South Wales, P.O. Box 1, Kensington, N.S.W., 2033, Australia.

Supported by grants from the Australian Kidney Foundation and the National Health and Medical Research Council of Australia. K.J.G. was supported by a National Health and Medical Research Council Medical Postgraduate Scholarship.
BV that occurs after delivery is due to renal salt and water losses. Because the natriuresis was greater if the lamb's arterial pressure rose after birth, it is possible that a high arterial pressure in the immediate newborn period could result in salt and volume depletion. (Pediatr Res 36: 506$513,1994)$

AII, angiotensin II
ADH, antidiuretic hormone
BV, blood volume
BV $_{\mathbf{N}}$, blood volume at delivery
FR $_{\mathbf{N a}} \mathbf{P}$, fractional reabsorption of sodium by the proximal
tubule
FR $_{\mathbf{N a}} \mathbf{D}$, fractional reabsorption of sodium by the distal
tubule
GFR, glomerular filtration rate

This study also examines in further detail the changes in renal sodium handling that occur after delivery to determine whether proximal and distal tubular sodium reabsorption are both affected or whether, as has been seen in other situations in which glomerulotubular balance has been altered (4-6), proximal tubular function is depressed and distal tubular function is enhanced. In addition, the renal response of the newborn to the first feed was studied.

\section{METHODS}

All procedures and protocols were approved by the Animal Care and Ethics Committee, University of New South Wales. Experiments were carried out in nine chronically prepared pregnant ewes at $139-145$ d gestation.

Surgical preparation and animal care. Under general anesthesia at 129-133 d gestation, catheters were inserted into a maternal carotid artery and jugular vein, into the amniotic cavity, and into both recurrent tarsal veins, a femoral artery, and the bladder of a fetus as previously 
described (7). At the end of surgery and on the following $2 \mathrm{~d}, 600 \mathrm{mg}$ of procaine penicillin and $750 \mathrm{mg}$ of dihydrostreptomycin (Hydropen, Bomac Laboratories, Asquith, New South Wales, Australia) were given intramuscularly to the ewe and into the amniotic cavity.

The ewes were housed in metabolic cages and had free access to water, lucerne chaff and oats. Vascular catheters were flushed daily with heparinized saline $(100$ $\mathrm{U} / \mathrm{mL}$ ). To minimize the risk of premature delivery, four of the ewes received one to four 250-mg doses of Proluton Depot (hydroxyprogesterone hexanoate, Schering, Berlin, Germany) intramuscularly between $136 \mathrm{~d}$ and the day of delivery.

Experimental protocol. ${ }^{3} \mathrm{H}$-inulin (Amersham, Buckinghamshire, UK; $3.6 \mu \mathrm{Ci} / \mathrm{kg})$ and lithium chloride $(250$ $\mu \mathrm{mol} / \mathrm{kg}$ ) were given i.v. to the fetus, followed by a continuous infusion of $0.6 \mu \mathrm{Ci} / \mathrm{kg} / \mathrm{h}$ and $10 \mu \mathrm{mol} / \mathrm{kg} / \mathrm{h}$, respectively, in $0.15 \mathrm{M}$ saline at $0.95 \mathrm{~mL} / \mathrm{h}$. Lithium chloride $(150 \mu \mathrm{mol} / \mathrm{kg})$ was also given i.v. to the ewe. The fetal bladder was drained for $30-45 \mathrm{~min}$ before the experiment, and the urine collected anaerobically into a glass burette under a $1-\mathrm{cm}$ layer of mineral oil. Urine was then collected for three 30-min periods. Maternal (4-5 mL) and fetal $(5-6.5 \mathrm{~mL})$ blood samples were taken at the midpoint of the second and third collection periods and replaced with equal volumes of $0.15 \mathrm{M}$ saline. Intraamniotic and fetal arterial pressures were recorded continuously using pressure transducers and a polygraph. Fetal arterial pressure was corrected for amniotic pressure. For each animal, results from the three fetal collection periods were averaged.

At the end of the fetal experiment, the ewe was taken from her cage. Under spinal/epidural anesthesia with $2 \%$ lignocaine (Xylocaine, Astra Pharmaceutical Products, Inc., Westboro, MA), the lamb was delivered by cesarean section. To prevent blood loss from either the lamb or the placenta, two ligatures were tied around the cord and the cord was cut between them. The lamb was briskly dried and placed in a sling under heating lamps. Respiration was spontaneous, but one lamb received supplementary oxygen.

After delivery, the ewe was milked to provide colostrum for the lamb's first feed. She was then killed with pentobarbitone sodium (Valobarb-Euthanasia solution, Animal Health Australia Limited, West Footscray, Victoria, Australia). The cotyledons were shelled from the maternal caruncles and weighed. The fetal membranes (amnion, allantois, and chorion without cotyledons) were also weighed.

After birth, the infusion of inulin and lithium chloride was continued, but no other infusions were given. Thirtymin anaerobic urine collections recommenced within 15-30 min of delivery and continued for at least $5 \mathrm{~h}$. The first six collection periods after birth were called L1-L6. If the urine flow rate was similar during $\mathrm{L} 5$ and L6, the lamb was fed in the seventh collection period $(n=7)$. In two lambs, the urine flow rate during L6 was higher than during L5, so feeding was delayed until the eighth col- lection period, by which time we felt that the early postnatal diuresis was complete. During the feeding period, called $\mathrm{D} 1$, the lambs received $70-85 \mathrm{~mL}$ of colostrum $(n=8)$ or cow's milk $(n=1)$. The following three collection periods were called D2-D4. Blood samples $(5-6.5 \mathrm{~mL})$ were taken at the midpoint of L2, L4, L6, D2, and D4 and replaced with equal volumes of $0.15 \mathrm{M}$ saline.

$B V$ measurements. Both fetal and lamb BV were measured by indicator dilution technique using ${ }^{51} \mathrm{Cr}$-labeled red blood cells. The dose of radioactivity injected was accurately determined as previously described (8). For the fetal measurement, labeled cells were injected the night before delivery and BV was determined $1 \mathrm{~h}$ after injection. For lamb measurements, a second injection of labeled cells was given after delivery. One $\mathrm{mL}$ of blood was taken before this second injection to measure the radioactivity remaining in the blood from the fetal injection. Correction was made for loss of radioactivity as a result of blood sampling. ${ }^{51} \mathrm{Cr}$ was counted in a Packard Auto Gamma counter (model 5650, Packard Instrument Co., Inc., Downers Grove, IL).

Biochemical analysis. Urinary $\mathrm{pH}$, bicarbonate, titratable acid, and ammonium excretion rates were determined on urine samples that had corresponding blood samples (for methods, see ref. 9). Arterial blood gases were measured using an IL pH/blood gas analyzer (micro 13, Instrumentation Laboratory, Lexington, MA) or a CIBA-Corning blood gas system (model 288, Medfield, MA). Plasma bicarbonate concentration was calculated using a modified Henderson-Hasselbach equation (10). Hematocrit was measured in duplicate using a hematocrit centrifuge and reader. The remaining blood was centrifuged at $2500 \mathrm{rpm}$ for $10 \mathrm{~min}$. Plasma and urine samples were stored at $-20^{\circ} \mathrm{C}$.

GFR was measured as the clearance of inulin. ${ }^{3} \mathrm{H}$ inulin levels in plasma and urine were measured using a Packard Tri-Carb liquid scintillation counter (model $300 \mathrm{CD}$ or $1900 \mathrm{TR}$ ). Sodium and potassium concentrations were measured using a Radiometer flame photometer (model FLM 3, Radiometer, Copenhagen, Denmark) and chloride levels determined with a Radiometer chloride titrator (model CM10). Osmolality was measured using an Advanced Digimatic Osmometer (model 3D II) or a Fiske One-Ten Osmometer (Needham Heights, MA). $\mathrm{FR}_{\mathrm{Na}} \mathrm{P}$ was calculated from the formula 1 - clearance of lithium/GFR; $F_{N_{\mathrm{Na}}} \mathrm{D}$ was calculated from the formula (clearance of lithium/GFR) - (clearance of sodium/GFR) (11). Lithium concentrations were measured by atomic absorption at $672 \mathrm{~nm}$ using an air acetylene flame (272 Atomic Absorption Spectrometer, Perkin-Elmer, Norwalk, CT).

Statistical analysis. Unless otherwise stated, results are expressed as mean \pm SEM, with $n=9$. Calculations and statistics were computed using an IBM-compatible personal computer and Statistical Package for the Social Sciences (SPSS/PC, SPSS Inc., Chicago, IL). Comparisons between time periods (before delivery and each period after delivery) were made using two-way analysis 
of variance. If a difference was found $(p<0.05)$, the Newman-Keuls test was used to determine which means were different. Regressions were computed by the method of least squares. A test for trend (12) was used to test for progressive changes in parameters with time after birth. $t$ tests (unpaired) were used to compare animals that had received Proluton Depot with those that were untreated.

\section{RESULTS}

The lambs were $142 \pm 1 \mathrm{~d}$ gestation at delivery and weighed $3.79 \pm 0.21 \mathrm{~kg}$. The cotyledons and membranes weighed $213 \pm 22 \mathrm{~g}$ and $184 \pm 13 \mathrm{~g}$, respectively $(n=7)$.

\section{Arterial Blood Gases (Table 1)}

After delivery of the lamb, arterial $\mathrm{Po}_{2}$ rose progressively $(p<0.001)$. $\mathrm{PCO}_{2}$ rose initially and then progressively fell $(p<0.005)$. Arterial $\mathrm{pH}$ fell initially and then rose progressively $(p<0.002)$, although it was still lower than fetal $\mathrm{pH}$ by D4. Lamb plasma bicarbonate levels were always lower than fetal plasma bicarbonate levels $(p<0.001)$.

\section{Plasma Electrolytes and Osmolality}

Fetal plasma osmolality, sodium level, and chloride level were $291 \pm 2 \mathrm{mosmol} / \mathrm{kg}, 146 \pm 1 \mathrm{mmol} / \mathrm{L}$, and 106 $\pm 1 \mathrm{mmol} / \mathrm{L}$, respectively. After birth, they rose to $297 \pm$ $2 \mathrm{mosmol} / \mathrm{kg}(p<0.005), 148 \pm 1 \mathrm{mmol} / \mathrm{L}(p<0.001)$, and $112 \pm 1 \mathrm{mmol} / \mathrm{L}(p<0.001)$, respectively, and remained elevated. They were not altered by feeding. Plasma potassium concentration, which was $4.2 \pm 0.1$ $\mathrm{mmol} / \mathrm{L}$ in the fetus, had fallen to $3.9 \pm 0.1 \mathrm{mmol} / \mathrm{L}$ by $\mathrm{L} 4$ $(p<0.025)$ but rose again after feeding to $4.3 \pm 0.1$ $\mathrm{mmol} / \mathrm{L}(p<0.01$ compared with $\mathrm{L} 4)$.

\section{BV and Hematocrit}

Fetal BV was $505 \pm 33 \mathrm{~mL}(133 \pm 4 \mathrm{~mL} / \mathrm{kg})$. At $60-75$ min after delivery (L2), BV was lower $(325 \pm 20 \mathrm{~mL}, 86$ $\pm 2 \mathrm{~mL} / \mathrm{kg}, p<0.001$, Table 1). Hematocrit was $0.40 \pm$ 0.01 before delivery and $0.43 \pm 0.01$ during L2 $(p<$ 0.025 ).

If it is assumed that 1 ) at the time the cord was clamped the hematocrit was the same as fetal hematocrit and 2) there was no change in red cell mass between the time the cord was clamped and the first BV measurement after birth $\left(\mathrm{BV}_{\mathrm{L} 2}\right)$, it is possible to calculate the $\mathrm{BV}_{\mathrm{N}}$ (i.e. $\mathrm{BV}$ when the cord is clamped) using the following equation: $\mathrm{BV}_{\mathrm{N}}=\left(\mathrm{Hct}_{\mathrm{L} 2} / \mathrm{Hct}_{\mathrm{F}}\right) \times \mathrm{BV}_{\mathrm{L} 2}$, where $\mathrm{Hct}_{\mathrm{F}}$ and $\mathrm{Hct}_{\mathrm{L} 2}$ are the hematocrits of the fetus and lamb (at L2), respectively. It was unlikely that circulating red cell mass would change significantly between delivery and L2 because splenic contraction does not alter the hematocrit in either the sheep fetus (13) or in lambs less than 1 wk old (14).

$\mathrm{BV}_{\mathrm{N}}$ was $345 \pm 20 \mathrm{~mL}(91 \pm 2 \mathrm{~mL} / \mathrm{kg})$. This was only $68.9 \pm 2.3 \%$ of the total fetal BV, although the weight of the lamb was $90.1 \pm 0.8 \%(n=7)$ of the combined weight of the fetus, cotyledons, and membranes. By subtraction, $160 \pm 19 \mathrm{~mL}$ of blood remained in the placenta and membranes after delivery; this represented $40 \pm 7 \%$ of their weight $(n=7)$.

BV then remained constant until D4, at which time it had risen to $365 \pm 28 \mathrm{~mL}(96 \pm 4 \mathrm{~mL} / \mathrm{kg} ; p<0.05$ compared with L2; Table 1). This was due to a rise in plasma volume. Plasma volume during D4 $(221 \pm 19 \mathrm{~mL})$ was higher than during L2 $(186 \pm 13 \mathrm{~mL} ; p<0.025)$. Red cell volume did not change. Hematocrit fell progressively $(p<0.02)$ from $0.43 \pm 0.01$ during $\mathrm{L} 2$ to $0.40 \pm 0.01$ during D4.

\section{Arterial Pressure and Heart Rate (Table 2)}

Systolic pressure did not change at delivery but was elevated during D1-D4. Although analysis of variance showed a change in diastolic pressure $(p=0.005)$, no difference between time periods could be found. Heart rate rose immediately after delivery. Although it then fell (compared with L1), it remained significantly above fetal levels for the rest of the experiment.

Table 1. Arterial blood gases and BV in ewes $(M)$, fetuses $(F)$, and lambs at the time the cord was clamped (N) and after birth $(L 2-D 4)(\text { mean } \pm S E M, n=9)^{*}$

\begin{tabular}{|c|c|c|c|c|c|}
\hline & $\begin{array}{c}\mathrm{Po}_{2} \\
(\mathrm{~mm} \mathrm{Hg}) \dagger\end{array}$ & $\begin{array}{c}\mathrm{PCO}_{2} \\
(\mathrm{~mm} \mathrm{Hg}) \dagger\end{array}$ & $\mathrm{pH}$ & $\begin{array}{c}\text { Plasma } \mathrm{HCO}_{3} \\
(\mathrm{mmol} / \mathrm{L})\end{array}$ & $\mathrm{BV}(\mathrm{mL})$ \\
\hline $\mathbf{M}$ & $97 \pm 3$ & $36 \pm 1$ & $7.46 \pm 0.01$ & $25.0 \pm 1.0$ & \\
\hline $\mathbf{F}$ & $21 \pm 1$ & $51 \pm 2$ & $7.36 \pm 0.01$ & $28.0 \pm 1.1$ & $505 \pm 33$ \\
\hline $\mathbf{N}$ & & & & & $345 \pm 20^{a}$ \\
\hline L2 & $38 \pm 3^{a}$ & $63 \pm 6^{a}$ & $7.17 \pm 0.04^{a}$ & $21.5 \pm 1.0^{a}$ & $325 \pm 20^{a}$ \\
\hline L4 & $51 \pm 3^{a, b}$ & $60 \pm 6$ & $7.23 \pm 0.04^{a, b}$ & $23.5 \pm 1.1^{a, b}$ & $339 \pm 26^{a}$ \\
\hline L6 & $54 \pm 4^{a, b}$ & $59 \pm 8$ & $7.24 \pm 0.05^{a, b}$ & $23.7 \pm 1.0^{a, b}$ & $335 \pm 23^{a}$ \\
\hline D2 & $58 \pm 5^{a, b}$ & $54 \pm 7$ & $7.27 \pm 0.05^{a, b}$ & $22.9 \pm 1.1^{a}$ & $340 \pm 24^{a}$ \\
\hline D4 & $66 \pm 4^{a, b, c}$ & $52 \pm 6^{b}$ & $7.28 \pm 0.04^{a . b}$ & $22.8 \pm 1.0^{a}$ & $365 \pm 28^{a, b}$ \\
\hline$p \ddagger$ & $<0.001$ & 0.016 & $<0.001$ & $<0.001$ & $<0.001$ \\
\hline
\end{tabular}

* L1-L6 refer to the first six 30-min collection periods after birth. The lambs were fed during D1, and the following three 30 -min collection periods were D2-D4. Blood samples were taken at the midpoint of L2, L4, L6, D2, and D4. Blood volume at N was calculated as described in the text. Superscript letters in the table have the following meanings: ${ }^{a}$, different from $\mathrm{F}^{b}{ }^{b}$, different from L2; and ${ }^{c}$, different from L4, L6, and D2, using a Newman-Keuls test.

† SI unit conversion: $1 \mathrm{~mm} \mathrm{Hg}=0.1333 \mathrm{kPa}$.

¥ Significance levels by analysis of variance, comparing fetal and lamb values. 
Table 2. Systolic pressure, diastolic pressure, and heart rate in fetuses (F), lambs after birth (L1-L6), and lambs during (D1) and after feeding (D2-D4) (mean $\pm S E M, n=9)^{*}$

\begin{tabular}{llcl}
\hline & $\begin{array}{c}\text { Systolic } \\
(\mathrm{mm} \mathrm{Hg}) \dagger\end{array}$ & $\begin{array}{c}\text { Diastolic } \\
(\mathrm{mm} \mathrm{Hg}) \dagger\end{array}$ & $\begin{array}{c}\text { Heart rate } \\
\text { (beats/min) }\end{array}$ \\
\hline F & $69 \pm 3$ & $43 \pm 3$ & $146 \pm 5$ \\
L1 & $70 \pm 2$ & $41 \pm 3$ & $220 \pm 10^{a}$ \\
L2 & $67 \pm 3$ & $41 \pm 3$ & $205 \pm 9^{a}$ \\
L3 & $65 \pm 2$ & $40 \pm 2$ & $184 \pm 8^{a, b}$ \\
L4 & $64 \pm 3$ & $40 \pm 3$ & $171 \pm 8^{a, b, c}$ \\
L5 & $67 \pm 3$ & $42 \pm 3$ & $174 \pm 8^{a, b, c}$ \\
L6 & $68 \pm 2$ & $41 \pm 3$ & $167 \pm 7^{a, b, c}$ \\
D1 & $74 \pm 2^{\text {c,d,e,f }}$ & $45 \pm 3$ & $186 \pm 9^{a, b}$ \\
D2 & $72 \pm 3^{d}$ & $45 \pm 3$ & $186 \pm 8^{a, b}$ \\
D3 & $73 \pm 3^{\text {c,d,e }}$ & $45 \pm 3$ & $175 \pm 5^{a, b, c}$ \\
D4 & $72 \pm 3^{d}$ & $44 \pm 3$ & $175 \pm 8^{a, b, c}$ \\
p & $<0.001$ & 0.005 & $<0.001$ \\
\hline
\end{tabular}

* Superscript letters in the table have the following meanings: ${ }^{a}$, different from fetal; ${ }^{b}$, different from $\mathrm{L} 1 ;{ }^{c}$, different from $\mathrm{L} 2 ;^{d}$, different from $\mathrm{L} 3$ and $\mathrm{L}_{4} ;{ }^{e}$, different from $\mathrm{L} 5$; and ${ }^{f}$, different from $\mathrm{L} 6$, using a Newman-Keuls test.

$\dagger$ SI unit conversion: $1 \mathrm{~mm} \mathrm{Hg}=0.1333 \mathrm{kPa}$.

$\ddagger$ Significance levels by analysis of variance.

\section{Renal Function}

GFR. Fetal GFR was $4.75 \pm 0.55 \mathrm{~mL} / \mathrm{min}$. When GFR after birth was expressed as a percentage of fetal GFR (fetal $=100 \%)$, it rose during L2 $(139 \pm 21 \%, p<0.02$, Fig. 1). However, it was not significantly greater than fetal GFR in all other periods.

Urine flow rate and osmolality. Immediately after birth, urine flow rate was not different from fetal urine flow rate $(0.41 \pm 0.07 \mathrm{~mL} / \mathrm{min})$. It then fell. Thus, urine flow rates during periods L3-L6 and D3-D4 were lower than those measured just after birth (Fig. 2A).

Urinary osmolality was $223 \pm 36 \mathrm{mosmol} / \mathrm{kg}$ in the fetus. Immediately after birth it was elevated (Fig. $2 B$ ). After feeding (D2), urinary osmolality fell (compared with $\mathrm{L} 2$ and $\mathrm{L} 3$ ). It then rose again to $417 \pm 46 \mathrm{mos}-$ $\mathrm{mol} / \mathrm{kg}$ at $\mathrm{D} 4$.

Free water clearance was positive before birth $(0.15 \pm$ $0.06 \mathrm{~mL} / \mathrm{min})$ and became negative after birth $(\mathrm{L} 2,-0.12$

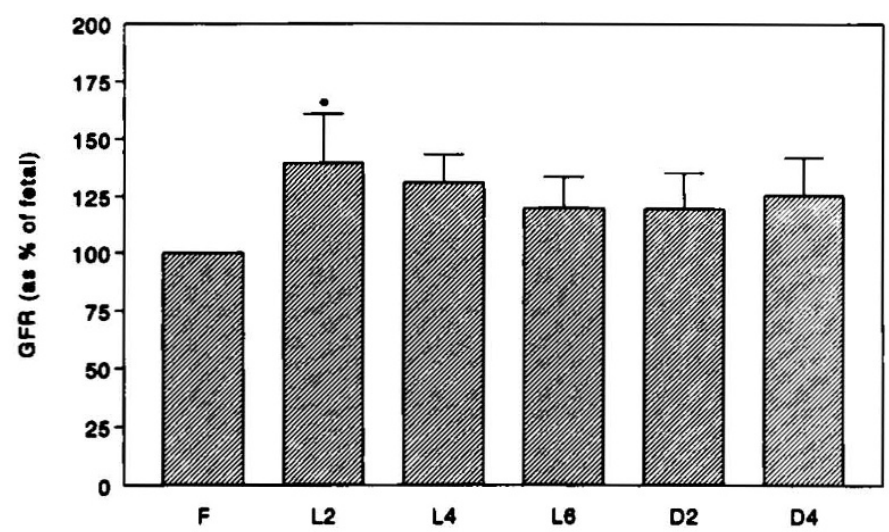

Figure 1. GFR expressed as a percentage of fetal GFR (fetal $=100 \%$ ), in fetuses $(F)$, lambs after birth $(L 2-L 6)$, and lambs after feeding (D2-D4). Values are mean \pm SEM, with $n=9 .{ }^{*}, p<0.02$ compared with fetal values. $\pm 0.01 \mathrm{~mL} / \mathrm{min}, p<0.001)$. Immediately after feeding, it was positive (D2, $0.10 \pm 0.05 \mathrm{~mL} / \mathrm{min} ; p<0.01 \mathrm{com}$ pared with $\mathrm{L} 2)$ but became negative again by $\mathrm{D} 4(-0.02$ $\pm 0.05 \mathrm{~mL} / \mathrm{min}$ ).

Urinary acid-base studies. Fetal $(n=8)$ urinary $\mathrm{pH}$ was $5.89 \pm 0.23$, and the excretion rates of bicarbonate, titratable acid, and ammonium were $2.7 \pm 1.0,4.2 \pm 1.2$, and $4.0 \pm 0.8 \mu \mathrm{mol} / \mathrm{min}$, respectively. There were no changes in these values after delivery or feeding $(\mathrm{L} 2, n=$ 8; L4, $n=7$; L6, $n=6$; D2, $n=7$; D4, $n=3$ ).

Sodium. Renal sodium excretion rose after birth from fetal levels of $8 \pm 2$ to $66 \pm 22 \mu \mathrm{mol} / \mathrm{min}$ during $\mathrm{L} 1$ ( $p<$ $0.001)$ and $44 \pm 16 \mu \mathrm{mol} / \mathrm{min}$ during L2 $(p<0.05)$, then it declined (Fig. 2C). This transient natriuresis was due to both an increase in the amount of sodium filtered and a decrease in the fractional reabsorption of sodium (L2, Table 3). Although the amount of sodium filtered was also high during $\mathrm{L} 4$, sodium excretion was low again because tubular reabsorption of sodium had improved (Table 3).

Despite the increase in the amount of sodium filtered during L2, the absolute amount of sodium reabsorbed by the proximal tubule was unchanged from before birth, i.e. $\mathrm{FR}_{\mathrm{Na}} \mathrm{P}$ fell during $\mathrm{L} 2$ (Table 3 ) and the amount of sodium delivered to the distal nephron increased (fetal, $259 \pm 42$; L2, $404 \pm 46 \mu \mathrm{mol} / \mathrm{min} ; p<0.01$ ). Both the absolute amount of sodium reabsorbed distally and the $\mathrm{FR}_{\mathrm{Na}} \mathrm{D}$ increased (Table 3). However, as a percentage of the amount of sodium delivered to it, distal reabsorption was lower during L2 $(90.4 \pm 2.2 \%)$ than in the fetus $(97.1 \pm$ $0.4 \%, p<0.001)$ or during any other period after birth $(\mathrm{L} 4,94.9 \pm 0.9 \%, p<0.005 ; \mathrm{L} 6,95.5 \pm 0.6 \%, p<0.001$; $\mathrm{D} 2,96.4 \pm 0.6 \%, p<0.001 ; \mathrm{D} 4,96.6 \pm 0.8 \%, p<0.001$ ). Therefore, the decrease in total fractional sodium reabsorption during $\mathrm{L} 2$ was due to a decrease in $\mathrm{FR}_{\mathrm{Na}} \mathrm{P}$ with incomplete compensation by the distal nephron.

By L4, FR $\mathrm{Na}_{\mathrm{P}} \mathrm{P}$ had increased and returned to levels similar to those measured in the fetus (Table 3). It continued to increase so that by $\mathrm{D} 4$ both the absolute amount of sodium reabsorbed proximally and $\mathrm{FR}_{\mathrm{Na}} \mathrm{P}$ were at their highest. Hence, the contribution of the distal tubule to fractional sodium reabsorption fell (Table 3). Despite this, during D4, there was still a significant relationship between distal sodium reabsorption and GFR $(r=0.929$, $p<0.001)$. In addition, $\mathrm{FR}_{\mathrm{Na}} \mathrm{P}$ was inversely related to GFR $(r=-0.802, p=0.009)$. $\mathrm{FR}_{\mathrm{Na}} \mathrm{D}$ was directly related to GFR $(r=0.830, p=0.006)$.

If it is assumed that each mole of anion reabsorbed is accompanied by an equal mole of sodium, the fractions of sodium reabsorbed as sodium chloride and sodium bicarbonate can be calculated. In the fetus, $72.6 \pm 0.5 \%$ of sodium was reabsorbed as sodium chloride, and $18.6 \pm$ $0.8 \%(n=8)$ as sodium bicarbonate. After birth, reabsorption as sodium chloride was higher (e.g. L2, $74.2 \pm$ $0.8 \%, p<0.005 ; \mathrm{D} 4,75.5 \pm 0.6 \%, p<0.001)$ and reabsorption as sodium bicarbonate was lower $(e . g$. L2, $14.6 \pm 0.7 \%, n=8, p<0.001 ; \mathrm{D} 4,16.4 \pm 0.5 \%, n=3$, $p<0.01)$. 
A

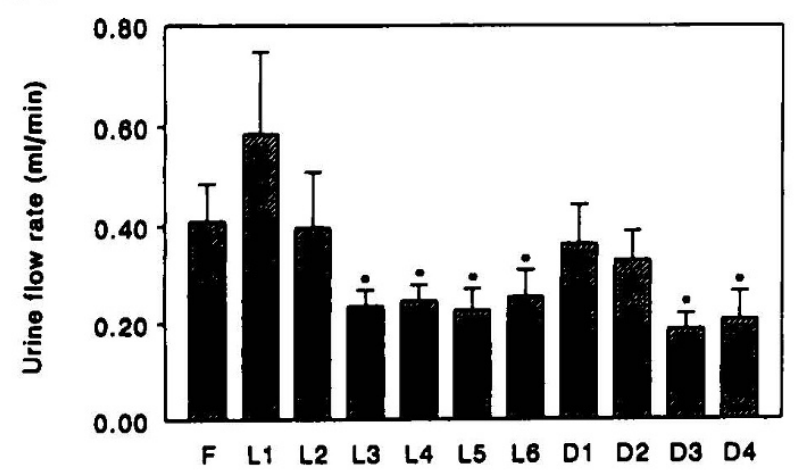

C

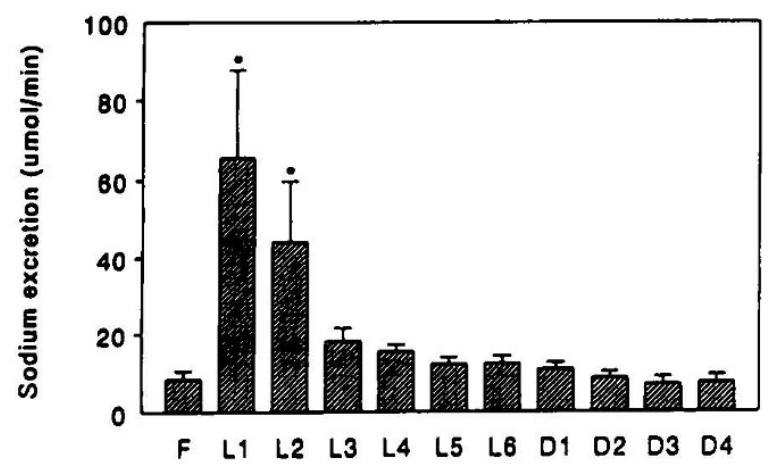

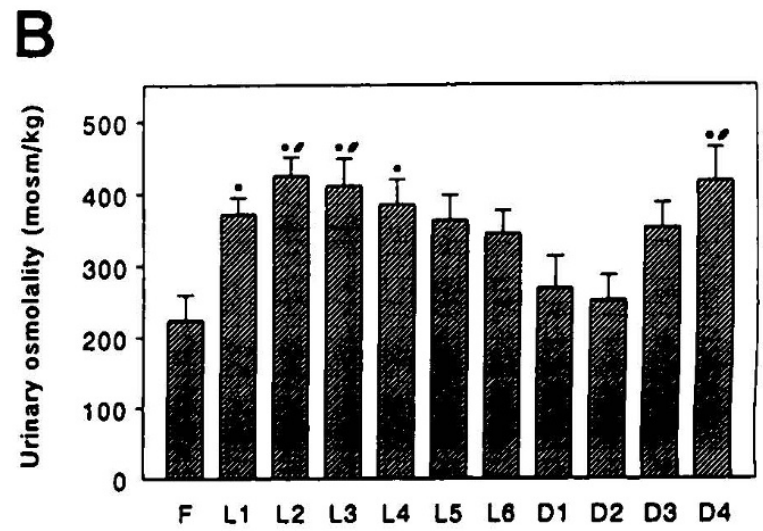

D

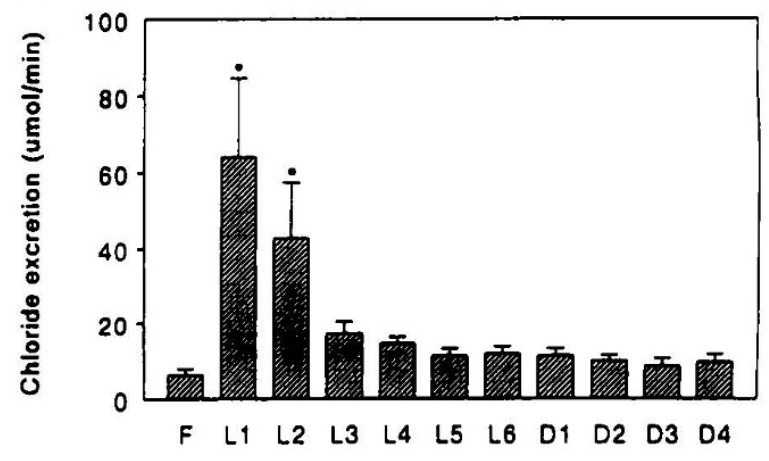

Figure 2. $A$, Urine flow rate (mL/min); $B$, urinary osmolality (mosmol/kg); $C$, sodium excretion rate ( $\mu \mathrm{mol} / \mathrm{min})$; and $D$, chloride excretion rate $(\mu \mathrm{mol} / \mathrm{min})$ in fetuses $(F)$, lambs after birth $(L 1-L 6)$, and lambs after feeding $(D 1-D 4)$. Values are mean $\pm \mathrm{SEM}$, with $n=9$. In $A, p=0.01$ by analysis of variance; *, different from L1. In $B, p<0.001$ by analysis of variance; *, different from fetal; \#, different from $\mathrm{D} 2$. In $C$, $p<0.001$ by analysis of variance; ${ }^{*}$, different from all periods without an asterisk. In $D, p<0.001$ by analysis of variance; ${ }^{*}$, different from all other periods.

Chloride. Chloride excretion followed the same pattern as sodium excretion (Fig. 2D). Filtered chloride was higher during $\mathrm{L} 2(653 \pm 45 \mu \mathrm{mol} / \mathrm{min}, p<0.025)$ and $\mathrm{L} 4$ $(657 \pm 67 \mu \mathrm{mol} / \mathrm{min}, p<0.025)$ than in the fetus $(504 \pm$ $57 \mu \mathrm{mol} / \mathrm{min})$. Fractional reabsorption of chloride was lower during L2 $(93.5 \pm 1.9 \%, p<0.001)$ than in the fetus $(98.9 \pm 0.2 \%)$ or any other period.

Potassium. Potassium excretion rose from $8.6 \pm 1.8$ $\mu \mathrm{mol} / \mathrm{min}$ in the fetus to $11.8 \pm 1.9 \mu \mathrm{mol} / \mathrm{min}$ during $\mathrm{L} 1$ $(p<0.05)$. It had fallen again by $\mathrm{L} 2(9.2 \pm 1.0 \mu \mathrm{mol} /$ min, $p<0.05$ compared with $L 1)$ and remained low. There were no significant changes in the filtered potas- sium load or fractional reabsorption of potassium after birth (fetal levels were $20.3 \pm 2.5 \mu \mathrm{mol} / \mathrm{min}$ and $64.2 \pm$ $5.4 \%$, respectively).

The urinary $\mathrm{Na} / \mathrm{K}$ ratio was $1.6 \pm 0.5$ in the fetus. It rose to $5.4 \pm 1.8$ during $\mathrm{L} 1(p<0.001)$ and $4.4 \pm 1.3$ during $\mathrm{L} 2(p<0.025)$ and then progressively declined $(p$ $<0.05$ ) to $1.0 \pm 0.2$ during $\mathrm{D} 4$.

Osmolar excretion. As would be expected from the changes in sodium and chloride excretions, osmolar excretion was higher in the first two periods after birth (L1, $200 \pm 48 \mu \mathrm{osmol} / \mathrm{min}, p<0.001 ; \mathrm{L} 2,154 \pm 35 \mu \mathrm{osmol} /$ $\min , p<0.05)$ than in the fetus $(74 \pm 11 \mu \mathrm{osmol} / \mathrm{min})$.

Table 3. Renal sodium handling in fetuses (F), lambs after birth (L2-L6), and lambs after feeding (D2-D4) (mean \pm SEM)*

\begin{tabular}{|c|c|c|c|c|c|c|c|}
\hline & $\mathbf{F}$ & L2 & $\mathbf{L} 4$ & L6 & D2 & D4 & $p \dagger$ \\
\hline Filt $(\mu \mathrm{mol} / \mathrm{min})$ & $695 \pm 80$ & $865 \pm 59^{a}$ & $869 \pm 90^{a}$ & $781 \pm 68$ & $762 \pm 52$ & $804 \pm 65$ & 0.049 \\
\hline $\mathbf{R}_{\mathrm{Na}} \mathbf{P}(\mu \mathrm{mol} / \mathrm{min})$ & $435 \pm 47$ & $461 \pm 42$ & $529 \pm 49$ & $493 \pm 30$ & $506 \pm 22$ & $574 \pm 26^{a, b}$ & 0.015 \\
\hline $\mathbf{F R}_{\mathbf{N a}} \mathbf{P}(\%)$ & $63.4 \pm 2.5$ & $53.4 \pm 3.4^{a}$ & $62.2 \pm 3.5^{b}$ & $64.9 \pm 3.1^{b}$ & $67.8 \pm 3.2^{b}$ & $73.2 \pm 3.4^{a, b, c, d}$ & $<0.001$ \\
\hline $\mathbf{R}_{\mathrm{Na}} \mathrm{D}(\mu \mathrm{mol} / \mathrm{min})$ & $251 \pm 40$ & $360 \pm 33^{a}$ & $325 \pm 65$ & $276 \pm 48^{b}$ & $247 \pm 43^{b}$ & $222 \pm 48^{b, c}$ & 0.002 \\
\hline $\mathrm{FR}_{\mathrm{Na}} \mathrm{D}(\%)$ & $35.5 \pm 2.4$ & $41.6 \pm 2.2^{a}$ & $35.9 \pm 3.5^{b}$ & $33.6 \pm 3.1^{b}$ & $31.1 \pm 3.1^{b}$ & $25.9 \pm 3.3^{a, b, c, d, e}$ & $<0.001$ \\
\hline $\mathbf{R}_{\mathrm{Na}}(\mu \mathrm{mol} / \mathrm{min})$ & $686 \pm 79$ & $821 \pm 54$ & $854 \pm 90$ & $769 \pm 67$ & $753 \pm 52$ & $797 \pm 64$ & NS \\
\hline $\mathrm{FR}_{\mathrm{Na}}(\%)$ & $98.9 \pm 0.2$ & $95.0 \pm 1.5^{a}$ & $98.1 \pm 0.3^{b}$ & $98.5 \pm 0.2^{b}$ & $98.9 \pm 0.2^{b}$ & $99.1 \pm 0.3^{b}$ & $<0.001$ \\
\hline
\end{tabular}

- Filt, the amount of sodium filtered; $R_{\mathrm{Na}} \mathbf{P}(\mu \mathrm{mol} / \mathrm{min})$, the amount of sodium reabsorbed by the proximal tubules; $R_{\mathrm{Na}} \mathrm{D}$, the amount of sodium reabsorbed by the distal tubules; $R_{\mathrm{Na}}$, the amount of sodium reabsorbed by the whole nephron; FR $\mathbf{N a}_{\mathrm{Na}}$, the percentage of the filtered sodium load reabsorbed by the whole nephron. The superscript letters in the table have the following meanings: ${ }^{a}$, different from fetal; ${ }^{b}$, different from L2; ${ }^{c}$, different from L4; ${ }^{d}$, different from L6; and ${ }^{e}$, different from D2, using a Newman-Keuls test.

+ Significance levels by analysis of variance. 
Osmolar excretion then remained low for the remainder of the experiment (D4, $67 \pm 7 \mu \mathrm{osmol} / \mathrm{min})$.

\section{Relationships between Natriuresis, BV, and Arterial Pressure after Birth}

The lambs excreted $2.6 \pm 0.9 \mathrm{mmol}$ of sodium and 23.5 $\pm 6.5 \mathrm{~mL}$ of fluid over the first $45 \mathrm{~min}$ that urine was collected after birth (urine collection began 15-30 min after delivery). Although the amounts excreted did not depend on the newborn BV or BV per $\mathrm{kg}$, there were excellent correlations between the amounts of sodium and fluid excreted in this 45 -min period and the fall in BV $(21 \pm 8 \mathrm{~mL})$ in the $1-1.25 \mathrm{~h}$ between delivery and $\mathrm{L} 2(r=$ $0.966, p<0.001$ and $r=0.960, p<0.001$; Fig. 3). Furthermore, the amount of fluid excreted was approximately equal to the fall in $\mathrm{BV}$ (mean difference, $3.0 \pm 2.4$ $\mathrm{mL}$ ), as was the clearance of sodium (mean difference, $2.8 \pm 2.6 \mathrm{~mL}$ ).

Although all lambs showed increases in sodium and fluid excretions after birth, these increases were accentuated if arterial pressure rose. In two lambs, systolic pressure rose by 10 and $16 \%$ and diastolic pressure by 23 and $26 \%$. These lambs also had the highest excretion rates of sodium $(6.5$ and $7.9 \mathrm{mmol})$ and fluid (52 and 61 $\mathrm{mL}$ ) in the first $45 \mathrm{~min}$ of urine collection. This may be partly explained by changes in GFR. The change in GFR between fetal life and L2 was directly related to the change in diastolic pressure $(r=0.802, p=0.009)$.

\section{Effects of Proluton Depot}

As explained above, four ewes received Proluton Depot to prevent premature delivery. Although treated $(n=$ 4 ) and untreated $(n=5)$ ewes had similar food and water intakes, treated ewes had lower plasma osmolalities (297 $\pm 1)$ and potassium levels $(4.05 \pm 0.11)$ and higher plasma $\mathrm{Na} / \mathrm{K}$ ratios $(36.9 \pm 0.9)$ than untreated ewes $(303 \pm 1$ $\mathrm{mosmol} / \mathrm{kg}, p<0.05 ; 4.39 \pm 0.06 \mathrm{mmol} / \mathrm{L}, p<0.05$; and $33.3 \pm 0.5, p<0.01)$. The corresponding fetal values were similar in both groups, but after birth lambs whose mothers had been treated with Proluton Depot had lower plasma osmolalities at L4 (291 $\pm 0.5 \mathrm{mosmol} / \mathrm{kg}), \mathrm{L} 6(290$
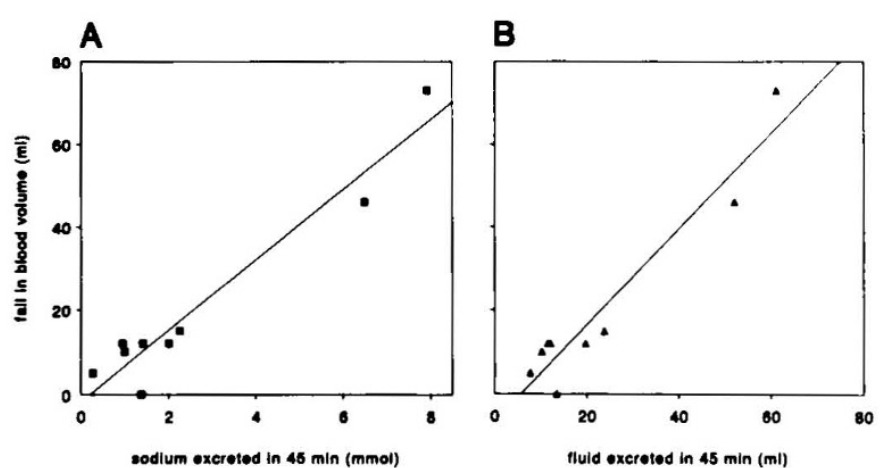

Figure 3. The fall in BV occurring in the $1-1.25 \mathrm{~h}$ between delivery and L2, plotted against the amounts of sodium $(A)$ and fluid $(B)$ excreted during the first $\mathbf{4 5}$ min that urine was collected after birth. In $A, r=$ $0.966, p<0.001, n=9$. In $B, r=0.960, p<0.001, n=9$. $\pm 2 \mathrm{mosmol} / \mathrm{kg})$, and D4 (294 $\pm 1 \mathrm{mosmol} / \mathrm{kg})$ than lambs whose mothers were not treated $(303 \pm 4 \mathrm{mosmol} / \mathrm{kg}, p<$ $0.05 ; 303 \pm 4 \mathrm{mosmol} / \mathrm{kg}, p<0.05$; and $305 \pm 3 \mathrm{mosmol} /$ $\mathrm{kg}, p<0.02$ ).

Fetuses of Proluton-treated mothers tended to have higher red cell volumes per $\mathrm{kg}$, but this difference was not significant until after birth $(p<0.05)$.

Fetuses of Proluton-treated mothers reabsorbed a greater fraction of the filtered sodium load $(99.4 \pm 0.04 \%)$ than fetuses of untreated mothers $(98.5 \pm 0.2 \%, p<0.02)$. The fraction reabsorbed proximally $(69.7 \pm 1.9 \%)$ was also greater $(58.3 \pm 2.5 \%, p<0.02)$. The fraction reabsorbed distally $(29.6 \pm 1.9 \%)$ was lower $(40.2 \pm 2.4 \% p<0.02)$, but when distal sodium reabsorption was expressed as a fraction of distal sodium delivery, it was greater in the treated group $(97.9 \pm 0.1 \%$ compared with $96.4 \pm 0.5 \%, p$ $<0.05$ ). There were no differences in fractional sodium reabsorptions (total, $\mathrm{FR}_{\mathrm{Na}} \mathrm{P}$, or $\mathrm{FR}_{\mathrm{Na}} \mathrm{D}$ ) between the two groups after birth.

The two groups were similar in the magnitude and time course of all changes occurring after delivery.

\section{DISCUSSION}

Effect of treatment with progesterone. Progesterone has been used in other studies, where fluid balance was not of concern, to prevent premature labor. However, in this study, because fluid balance was examined and progesterone is known to interact with glucocorticoid and mineralocorticoid hormones, treated and untreated animals were compared.

Surprisingly in both ewe and fetus, it appeared as though progesterone was a mineralocorticoid agonist, i.e. treated animals had lower maternal plasma potassium levels, higher maternal $\mathrm{Na} / \mathrm{K}$ ratios, and higher fetal distal sodium reabsorptions as a fraction of distal sodium delivery. However, progesterone is thought to be a mineralocorticoid antagonist (15).

It should be emphasized that progesterone was given to ewes that we suspected might go into labor prematurely, e.g. two that carried twins, and it is possible that the differences seen in progesterone-treated animals were in fact due to other uncontrolled variables. Furthermore, any differences between the two groups of animals were largely in baseline values. There was no difference between the two groups in the magnitude or time course of changes occurring after delivery.

Early changes in renal function after delivery. This study confirms the finding that lambs delivered by cesarean section have a transient natriuresis soon after birth (2). This natriuresis was due to both an increase in the filtered sodium load and a decrease in $\mathrm{FR}_{\mathrm{Na}} \mathrm{P}$; the distal nephron failed to fully compensate for the $10 \%$ decrease in $\mathrm{FR}_{\mathrm{Na}} \mathrm{P}$.

Obviously, our conclusions regarding the sites of sodium handling after birth depend on values obtained using the clearance of lithium to determine $\mathrm{FR}_{\mathrm{Na}} \mathrm{P}$. We have shown that there is good agreement between $F_{\mathrm{Na}} \mathrm{P}$ measured using lithium clearance and $\mathrm{FR}_{\mathrm{Na}} \mathrm{P}$ measured 
using distally acting diuretics in the fetus (11) but have not tested this in the newborn. However, if significant postproximal reabsorption of lithium occurred after birth, the apparent $\mathrm{FR}_{\mathrm{Na}} \mathrm{P}$ would be falsely elevated. Therefore, the fall in $\mathrm{FR}_{\mathrm{Na}} \mathrm{P}$ after delivery would have been greater than we have calculated.

The filtered sodium load rose after birth because GFR increased (Fig. 1). In addition, there was a small rise in plasma sodium concentration $(2 \mathrm{mmol} / \mathrm{L})$. Probably the lambs became dehydrated due to water evaporation from the skin and lungs (16).

A rise in GFR after birth has also been reported by others $(2,17)$. In the present study, we showed that a greater rise in GFR after birth correlated with a greater rise in diastolic pressure. In both adult and newborn animals, outer cortical blood flow is more dependent on arterial pressure than inner cortical blood flow (18), so there may have been a change in the distribution of intrarenal blood flow to include the superficial glomeruli (18). If indeed GFR increased mainly in superficial glomeruli, this would explain the lack of a corresponding increase in proximal tubular sodium reabsorption in response to this increased filtered sodium load, because the most superficial nephrons are the least mature (4).

Obviously, hormonal changes associated with delivery could have influenced postnatal renal function, although these endocrine changes would not be as great after cesarean section (especially without labor) as they are after vaginal delivery $(19,20)$. However, even after cesarean section, lambs have elevated levels of $\mathrm{ADH}$, plasma renin activity, AII, aldosterone, catecholamines, and atrial natriuretic peptide, particularly within the first hour $(17,21-23)$. In addition, cortisol levels increase toward the end of gestation (24).

Of these, cortisol $(5,25)$, atrial natriuretic peptide $(26)$, ADH (6), epinephrine (27), and even AII (28) may have contributed to the natriuresis. By contrast, the high level of sympathetic nervous activity after birth (suggested by the tachycardia) probably limited the natriuresis (23).

Because $\mathrm{FR}_{\mathrm{Na}} \mathrm{P}$ fell after birth, more sodium was presented to the distal nephron, and distal sodium reabsorption increased. This response was expected because increases in distal delivery enhance distal reabsorption $(4-6,25)$. In addition, elevated aldosterone levels (23) may have contributed.

Newborn BV. BV was measured to determine whether the postnatal natriuresis was due to volume expansion. Although BV per kg in the fetus $(133 \pm 4 \mathrm{~mL} / \mathrm{kg})$ was high compared with data obtained by others using ${ }^{51} \mathrm{Cr}$-labeled red cells $(13,29)$, it was similar to other studies from this laboratory using the same breed of sheep (8). There is a wide variation in fetal weight between breeds, and the BV per $\mathrm{kg}$ is higher in breeds with small fetuses (like the Merino cross breeds used in this study) than in breeds with larger fetuses (29).

$\mathrm{BV}_{\mathrm{N}}$ could not be measured directly because rapid shifts of fluid into or out of the vascular compartment may occur at birth $(30,31)$. It was calculated from the BV at $\mathrm{L} 2$ and the change in hematocrit. $\mathrm{BV}_{\mathrm{N}}$ per $\mathrm{kg}$ ranged from 84 to $103 \mathrm{~mL} / \mathrm{kg}$. Within this range, all lambs showed a natriuresis. However, the amounts of sodium and fluid excreted (ranges: 0.3 to $7.9 \mathrm{mmol}$ and 7.7 to 61 $\mathrm{mL}$, respectively, in $45 \mathrm{~min}$ ) varied much more than $\mathrm{BV}_{\mathrm{N}}$ per $\mathrm{kg}$ and did not depend on $\mathrm{BV}_{\mathrm{N}}$ per $\mathrm{kg}$. Thus, our hypothesis that the extent of the natriuresis would be related to the $B_{\mathrm{N}}$ per $\mathrm{kg}$ was not supported.

However, a more significant finding did emerge, i.e. the amounts of sodium and fluid excreted soon after birth determined the lamb's subsequent BV (Fig. 3). The fall in BV that occurred in the first $1-1.25 \mathrm{~h}$ after birth was approximately equal to the amount of fluid excreted and the clearance of sodium in the first $45 \mathrm{~min}$ of urine collection after birth. Thus, renal excretion of salt and water is the major factor responsible for the fall in plasma volume that occurs after birth in infants and lambs. Previously, this fall in BV has been attributed to transudation of fluid into the extravascular spaces $(30,31)$. Furthermore, because the amounts of sodium and fluid excreted were much greater when arterial pressure increased by more than $10 \%$ after birth, it can be predicted that sick newborns with high arterial pressures are more likely to become volume and sodium depleted.

Changes related to feeding. To determine whether feeding influenced renal function in newborn lambs, lambs were fed colostrum. We delayed feeding until the seventh or eighth 30 -min period after birth to ensure that the urine flow rate was stable and the early postnatal natriuresis was complete before feeding (D1). Figure 2 and Table 3 confirm that renal function was relatively stable before D1.

Immediately after feeding, urinary osmolality fell and free water clearance became positive. Without a control group of unfed lambs, we cannot be certain that these changes were due to feeding, but their temporal relationship to feeding and their return to prefeeding levels during D3 and D4 are very suggestive that these changes were indeed due to feeding. The rapidity of the response (within $30 \mathrm{~min}$ ) suggests that these changes were caused by inhibition of ADH secretion, mediated via oropharyngeal receptors (32), rather than related to absorption of the colostrum.

During and after feeding, systolic pressure rose (Table 1). By contrast, the arterial pressure of unfed lambs at a similar time after birth was lower (21) or unchanged from soon after birth (17). Perhaps vigorous movement of the lambs within the sling during and after feeding and volume expansion secondary to absorption of colostrum (plasma volume was increased during D4) contributed to the increase in arterial pressure.

Late changes in renal function. It is important to note that the postnatal natriuresis was only transient. Thus, by $5.5 \mathrm{~h}$ after birth (D4), the amount of sodium reabsorbed by the proximal tubule was greater than in the fetus, even though the amount of sodium filtered was similar to the amount filtered by the fetus. Thus, at this time, $\mathrm{FR}_{\mathrm{Na}} \mathrm{P}$ 
was $73.2 \pm 3.4 \%$, a value similar to that measured in adult sheep in this laboratory $(80.6 \pm 1.7 \%)(11)$.

The increase in proximal sodium reabsorption by $\mathrm{D} 4$ could have been due to increased availability of oxygen (Table 1), changing hormone profiles (atrial natriuretic peptide, catecholamine, AII, and ADH levels have fallen by $4-5 \mathrm{~h}$ after birth) (21-23), increased proximal tubular Na-K-ATPase activity, or an increase in plasma glucose secondary to feeding (33).

In summary, it was found that the natriuresis in newborn lambs was due to an increase in GFR and depression of $\mathrm{FR}_{\mathrm{Na}} \mathrm{P}$. The hypothesis that the extent of the natriuresis would be related to the newborn BV per $\mathrm{kg}$ was not supported. However, it was found that the natriuresis was greater if arterial pressure rose after birth and that the extent of this loss of fluid and electrolytes was responsible for the extent by which BV fell in the first $1-1.25 \mathrm{~h}$ after birth. This postnatal natriuresis was only transient, and by $5.5 \mathrm{~h}$ after birth, $\mathrm{FR}_{\mathrm{Na}} \mathrm{P}$ was similar to that found in adult sheep.

Acknowledgments. The authors thank Dr. A. D. Stevens, G. Ustandag, and R. Carlo-Stella for their excellent assistance and R. I. Menzies for measuring the lithium levels.

\section{REFERENCES}

1. Strauss J, Daniel SS, James LS 1981 Postnatal adjustment in renal function. Pediatrics 68:802-808

2. Smith FG, Lumbers ER 1988 Changes in renal function following delivery of the lamb by caesarian section. J Dev Physiol 10:145-148

3. Daniel SS, James LS, Strauss J 1981 Response to rapid volume expansion during the postnatal period. Pediatrics 68:809-813

4. Kleinman LI 1982 Developmental renal physiology. Physiologist 25:104-110

5. Towstoless MK, McDougall JG, Wintour EM 1989 Gestational changes in renal responsiveness to cortisol in the ovine fetus. Pediatr Res 26:6-10

6. Gibson KJ, Lumbers ER 1993 The roles of arginine vasopressin in fetal sodium balance and as a mediator of the effects of fetal "stress." J Dev Physiol 19:125-136

7. Lumbers ER, Stevens AD 1983 Changes in fetal renal function in response to infusions of a hyperosmotic solution of mannitol to the ewe. J Physiol (Lond) 343:439-446

8. Kingsford NM, Lumbers ER 1989 Effects of autonomic blockade on the hypertensive response of the fetus to hyperosmolality. Clin Exp Pharmacol Physiol 16:873-883

9. Kesby GJ, Lumbers ER 1986 Factors affecting renal handling of sodium, hydrogen ions, and bicarbonate by the fetus. Am J Physiol 251:F226-F231
10. Armentrout T, Katz S, Thornburg KL, Faber JJ 1977 Osmotic flow through the placental barrier of chronically prepared sheep. Am J Physiol 233:H466$\mathrm{H} 474$

11. Lumbers ER, Hill KJ, Bennett VJ 1988 Proximal and distal tubular activity in chronically catheterized fetal sheep compared with the adult. Can J Physiol Pharmacol 66:697-702

12. Wallenstein S, Zucker CL, Fleiss JL 1980 Some statistical methods useful in circulation research. Circ Res 47:1-9

13. Brace RA 1983 Blood volume and its measurement in the chronically catheterized sheep fetus. Am J Physiol 244:H487-H494

14. Block SM, Pixley JE, Wray AH, Ray D, Barnes KD, Engstrom PC, Rose JC 1989 Blood volume restitution after hemorrhage in the newborn lamb. Am J Physiol 257:R647-R652

15. Reid AF, Spence CD, Coghlan JP, Denton DA, Whitworth JA, Scoggins BA 1987 Steroid antagonism of the hypertensinogenic activity of adrenocortical steroids. J Steroid Biochem 27:977-983

16. Doyle LW, Sinclair JC 1982 Insensible water loss in newborn infants. Clin Perinatol 9:453-481

17. Nakamura KT, Matherne GP, McWeeny OJ, Smith BA, Robillard JE 1987 Renal hemodynamics and functional changes during the transition from fetal to newborn life in sheep. Pediatr Res 21:229-234

18. Aperia A, Broberger O, Herin P, Joelsson 11977 Renal hemodynamics in the perinatal period. Acta Physiol Scand 99:261-269

19. Broughton Pipkin F, Kirkpatrick SM, Lumbers ER, Mott JC 1974 Renin and angiotensin-like levels in foetal, newborn and adult sheep. J Physiol (Lond) 241:575-588

20. Jones CM, Greiss FC 1982 The effect of labor on maternal and fetal circulating catecholamines. Am J Obstet Gynecol 144:149-153

21. Leffler CW, Crofton J, Brooks DP, Share L, Hessler JR, Green RS 1985 Changes in plasma arginine vasopressin during transition from fetus to newborn following minimal trauma delivery of lambs and goats. Biol Neonate 48:43-48

22. Davidson D 1987 Circulating vasoactive substances and hemodynamic adjustments at birth in lambs. J Appl Physiol 63:676-684

23. Smith FG, Smith BA, Guillery EN, Robillard JE 1991 Role of renal sympathetic nerves in lambs during the transition from fetal to newborn life. J Clin Invest 88:1988-1994

24. Challis JRG, Jones CT, Robinson JS, Thorburn GD 1977 Development of fetal pituitary-adrenal function. J Steroid Biochem 8:471-478

25. Hill KJ, Lumbers ER, Elbourne I 1988 The actions of cortisol on fetal renal function. J Dev Physiol 10:85-96

26. Shine P, McDougall JG, Towstoless MK, Wintour EM 1987 Action of atria natriuretic peptide in the immature ovine kidney. Pediatr Res 22:11-15

27. Ervin MG, Castro R, Sherman DJ, Ross MG, Padbury JF, Leake RD, Fisher DA 1991 Ovine fetal renal and hormonal responses to changes in plasma epinephrine. Am J Physiol 260:R82-R89

28. Stevenson KM, Lumbers ER 1992 Effects of indomethacin and angiotensin II on fetal renal function. FASEB J 6:4686(abstr)

29. Broughton Pipkin F, Kirkpatrick SML 1973 The blood volumes of fetal and newborn sheep. Q J Exp Physiol 58:181-188

30. Linderkamp O 1982 Placental transfusion: determinants and effects. Clin Perinatol 9:559-592

31. Yao AC, Lind J 1974 Placental transfusion. Am J Dis Child 127:128-141

32. Blair-West JR, Gibson AP, Woods RL, Brook AH 1985 Acute reduction of plasma vasopressin levels by rehydration in sheep. Am J Physiol 248:R68R71

33. Eales FA, Murray L, Small J 1982 Effects of feeding ewe colostrum, cow colostrum or ewe milk replacer on plasma glucose in newborn lambs. Vet Rec $111: 451-453$ 